\title{
The Influence of Social Media and Environmental Factors on Academic Performance of Student Nurses in South-West Nigeria
}

\author{
Ezekiel Olusegun Babatunde, PhD \\ Institute of Education, University of Ibadan, Ibadan
}

doi: 10.19044/esj.2017.v13n10p295 URL:http://dx.doi.org/10.19044/esj.2017.v13n10p295

\begin{abstract}
The growing popularity and consideration of social networking sites having the ability to enhance interaction, academic participation and performance among lecturers and students respectively underscored an investigation into the influence of social media and environmental factors on academic performance of student nurses in Southwest Nigeria. The study is a survey design that adopted correlational research type. The population comprised all Student Nurses in all the Nursing Schools in Southwest Nigeria. Six schools purposively selected and a sample of 300 students randomly selected participated in the study. Two instruments: Social Media and Environmental Factor Questionnaire (SMEFQ) r=0.85 and Student Nurses Achievement Test (SNAT), r=0.72 was used to collect data. Three research questions guided the study and data collected was analysed using descriptive and inferential statistics. Result revealed that the three predictor variables correlated with each other in predicting students' academic achievement. It also showed that Facebook $\beta=(-.162), \mathrm{t}(-1.436)=.155$, p>.005 contributed most among the predictor variables while the two predictors (social media and environmental factors) could not predict students academic performance in Nursing $\left(\mathrm{F}_{(2,77)}=1.214, \mathrm{P}=0.303\right)$. It is recommended that students be encouraged to use social media adequately for academic purposes while government improve school physical structures and provide conducive learning environment for academic excellence.
\end{abstract}

Keywords: Social media, Environment, Student Nurses, Academic performance

The world is today celebrating the improvements in communication technology which has broadened the scope of communication through Information and Communication Technologies (ICT). The expansion in technology has also affected internet software, thus leading to chatting sites 
known by the name "social media". Social network is a social structure made up of individuals or organizations called "nodes", which are connected by one or more specific types of interdependency, such as friendship, kinship, common interest, financial exchange, dislike, sexual relationships or relationships of beliefs, knowledge or prestige (Adeboye cited in Asemah \& Edegoh,2012).

Social media can also be referred to as a map of specified ties, such as friendship, between the nodes being studied. The nodes, to which an individual is thus connected, are the social contacts of that individual; the network can also be used to measure social capital - the value that an individual gets from the social network. Social networking sites include: Yahoo Messenger, Facebook Messenger, Blackberry Messenger (BBM), Google talk, Google+ Messenger, iPhone, Androids and so on. These networking sites are used by most people to interact with old and new friends, physical or internet friends (Adeboye cited in Asemah \& Edegoh, 2012).

Asemah, Okpanachi and Edegoh (2013) revealed that the exposure or assess to social media affects the academic performance of students. Students who spend more time on social media are likely to perform poorly in their academics. This is because, instead of reading their books, they spend their time charting and making friends via the social media and this will definitely have negative effect on their academic performance, because inadequate study will lead to poor academic performance, This trend could likely predict or influence students' negative perception of social media. This phenomenon which has become a source of worry to many who believe in knowledge and skill acquisition, incidentally, calls for the regulation of the excessive and unprofitable use of the social media in educational institutions.

In the past years, social media websites have become common; giving young people a new way to interact with each other and communicate with the world. Social networking became popular between 2004 and 2006, after Facebook and MySpace were created. Facebook, for example has over 500 million members and it is still growing and approximately 85\% of undergraduate students are Facebook users (Schneider, 2009). These numbers are expected to grow since Facebook users will continue to grow. And this is not only true for Facebook, numbers for Wikipedia, Google and YouTube users closely follow as well (University of New Hampshire, 2009).

Social networking websites provide tools by which people can communicate, share information, and create new relationships. With the popularity of social networking websites on the rise, our social interaction is affected in multiple ways as we adapt to our increasingly technological world. Today, Social media is a powerful new form of communication and its use cut across rank, profession and age. There are different types that 
have support for educators (blogging, Edublogawards, Teacher Tube, Twitter); delivery of content (MIT's Open Course Ware, iTunesU) and social learning (Facebook, Google+, blogs, LinkedIn and You Tube). Collaborated projects e.g Wikipedia, blogs. Micro blog Twitters, Content communities such as YouTube, Flicker, Myspace.com, meet Up, del.icio.us stumble Upon.

Social network sites have attracted considerable attention among scholars and educators due to the growing popularity among students of the sites influencing the free access for whom ever that desire to interact with friends and lecturers with a view to generating collective knowledge and having the potential to effect students' academic performance. However, studies appear from two opposing views on the influence of social media on users. While proponents argue that it allows users in connecting people of common interest and value, opponents claim that excessive use of these sites affect the social, mental and physical health of the users. Ogbemudia \& Aiasa (2013) asserts that social media enable students to connect with friends and share information as well as organize their offline meetings and group work. However, Ogbemudia \& Aiasa (2013) assert that while evidence for Social Media Anxiety Disorder is largely at present, a study conducted in UK among social media users found that more than 50\% users indicated that social media use is associated with negative impact.

Unlike the social media, environment also influences students' academic performance. This according to Orlu (2013) is instructive to the major role which the environment plays in the life of every individual whether students, teachers, employer or employee. Though some people are yet to believe that environment brings about better performance. While reviewing the article of Udoh "The Environmental Health Problems in Nigeria Schools", Orlu (2013) identified some unhealthy practices like: sitting of schools, inadequate facilities, poor ventilation etc. that may adversely affect the health of students and teachers, which will in turn reflect on students' academic performance.

Odeh, Oguche, \& Ivagher (2015) see environmental factors as facilities that are available to facilitate students learning outcome. It includes books, audio-visual, software and hardware of educational technology. So also, classroom size, sitting position and arrangement, availability of tables, chairs, chalkboards, shelves on which instruments for practical are arranged. Grant (2008) states that environment also includes a host of structures such as buildings, furniture's, equipment, instructional materials, the teachers, the peer group and other people involved in the development of a child. Booth and Okeke (2007) looked at environment as the physical environment (e.g. facilities and equipment), school policies (e.g. time allocated for physical 
and health education, sport) and school practices regulating PE and Sport as well as strategies to promote participation).

Akeem (2008) emphasized that environmental factors like school facility, school climate and home background depicts a place where the student/child functions. This includes home, the school, the peer group, the classroom, the totality of the child's upbringing including his spiritual life, tissue needs, social needs and psychological needs. It is defined not to mean only the place in which the child lives (physical) but also the people with which he comes in contact with or socializes with, increase school enrolment and students interests in learning. Thus, the issue of environment has generated much research interest in order to put into use by private individuals', mission, communities or government proprietors an environment that will be stimulating and will enhance academic performance of students.

Nwangwu (2009) gave the characteristics of environmental factors enhancing students' academic performance to include school buildings, classrooms, furniture's, playgrounds, sporting facilities, laboratories, libraries and equipment which aid the teachers in effective delivery of lesson. According to State of Magne, Meeks, Wellens \& Hooley (2009), school environment includes the physical and aesthetic surroundings and the psychological climate and culture of the school. Farombi (2007) observed that school environment may have negative influence on students' academic performance especially if such environment lacks good school climate, instructional materials, discipline, physical facilities, has poor teacher quality, questionable school location, small class size and over population of students in classrooms. He further opined that school facilities are a potent factor to quantitative education.

The importance of environmental factors to influencing students' academic performance in education cannot be overemphasized. This is because, environmental factors have tremendous influence in the quality of teaching students receives and the extent of attention they pay to lesson in school. This implies that schools that fail to provide the necessary learning facilities and create conducive atmosphere for teaching and learning may hardly put in the best in their students especially in the area of academic performance. This scenario has been among the reason for poor academic performance of students. Ajewole and Okebukola (2009) corroborated this view by stating that a host of these factors may surround students' poor performance in school among which may include: poor study habits, lack of resource materials, poor school climate, indiscipline, inadequate facilities, teachers' ineffectiveness, the teaching method and the type of learning environment available for both the students and the teachers. 
Byoung-suk,.(2012) stated that children need safe, healthy and stimulating environment in which to grow and learn. During the school year, children can spend 6 to 8 hours at the school where the environment plays a significant/critical role in child development. More of the time is spent in the school or travelling to and from school. This condition requires careful planning and designing to optimize experiences that support education, health and stewardship. Therefore, the school environment is of paramount importance in shaping and reshaping intellectual ability. However, supportive and favourable school environment with enough learning facilities and favourable climate makes students more comfortable, more concentrated on their academic activities that result in high academic performance. The forces of the environment begin to influence growth and development of the individual right from the womb of his mother. The favourable school environment provides the necessary stimulus for learning experiences. The children spend most of their time in school, and this school environment is exerting influence on performance through curricular, teaching technique and relationship (Arul Lawrence, 2012).

However, educational institutions are intimately linked with society as a whole. They are the temple of knowledge and agent of social change and transformation. The general condition of our schools, colleges and universities are a matter of great concern to the nation. It plays a significant role in the development of the personality of the students. As the students spend most of their life at school, the school environment is highly responsible for the inculcating of high values into them. The Council for the Advancement of Standards (CAS) reported that academic "advising programs must identify environmental conditions that may positively or negatively influence student academic achievement” (CAS, 2009).

However, school climate is larger than any one person's experience. When people work together, a group process emerges that is bigger that any one person's actions. A comprehensive assessment of school climate includes major spheres of school life such as safety, relationships, teaching and learning, and the environment as well as larger organizational patterns (e.g. from fragmented to shared; healthy or unhealthy). How we feel about being in school and these larger group trends shape learning and student development .Environmental influence before now have not been considered as one of the factors that affect academic performance in schools hence it has little or no attention in educational discourse and consideration. But over the past decade remarkable studies have indicated a correlation between the environment and academic performance of students. Environment plays major role in the life of every individual whether a student, teacher, employer or employee. 
The emergence of social media as a result of advancement in technology and expansion in internet software has raised eye brows among academics on its (social media) impacts on studies. Students at all levels of learning now have divided attention to studies as a result of available opportunities to be harnessed from social media. Whether these opportunities promote studies is a question that needs to be answered. Similarly, there are some environmental factors in most Nigerian institutions like insufficient facilities, deteriorated buildings and bad ventilation which may hinder learning to take place. Hence it is pertinent to critically look at the environmental factors that influence academic performance of student nurses. This study therefore examined the influence of social media and environmental factors on academic performance of Student Nurses in South West Nigeria.

The study is a survey type that adopted correlational design. Three research questions that guided the study are:

1. What is the contribution of Facebook, Google and Wikipedia on the academic performance of student nurses in South-West Nigeria?

2. What is the influence of School environment on the academic performance of student nurses in South-West Nigeria?

3. What is the joint contribution of social media and environmental factors on the academic performance of student nurses in South-West Nigeria?

The population comprises all the 2,400 student nurses in all the six selected Nursing Schools in South-West Nigeria. One school of nursing was purposively selected from each of the six states in South-West and 300 students randomly sampled using Taro Yamene proportionate to size sampling technique participated in the study. Using a simple ratio, approximately, 49 student nurses were selected from each school and 17 students from each class. The students in each school were stratified by their classes: year one, two, and three. All selected Schools have various degrees of students from part one to part three.

Two instruments: Social Media and Environment Questionnaire (SMEQ), with Cronbach alpha coefficient of 0.85 and Student Nurses Achievement Test (SNAT) with a reliability of $r=0.72$ were used to collect data. SMEQ instrument is divided into two sections. Section A comprised the demographic data of respondents which include age, gender, ethnicity, religion, and family type, position among the full siblings, etc. Section B consists of 19 items scored on a 5 -points likert scale $(0=$ =never; 1=infrequently; 2=sometimes; 3=frequently; 4=always) The second instrument, SNAT consists 30 multiple choice items with options A - D. Data collected was analysed using descriptive and inferential statistics at 0.05 level of significance. 
Table 1: Demographic data of Respondents

\begin{tabular}{|c|c|c|c|c|}
\hline S/N & Items & Variables & Frequency & Percentage (\%) \\
\hline 1. & Gender & Male & 35 & 11.7 \\
& & Female & 265 & 88.3 \\
\hline 2. & Ethnicity & Yoruba Igbo & 240 & 80 \\
& & Hausa & 50 & 17 \\
& & & 10 & 3 \\
\hline 3. & Religion & Christianity & 210 & 70 \\
& & Islam & 90 & 30 \\
\hline 4. & Family type & Monogamous & 245 & 82 \\
& & Polygamous & 55 & 18 \\
\hline 5. & Level & Year one Year & 100 & 33.3 \\
& & two Year three & 100 & 33.3 \\
& & & 100 & 33.3 \\
\hline
\end{tabular}

Table 1 shows the demographic data of the respondents used in the study. From the table, majority 265(88.3\%) of the participants are females while only $35(11.7 \%)$ are males. This is in line with Eswi, Radi \& Youssri (2013) on Stress/Stressors as Perceived by Baccalaureate Saudi Nursing students. Moreover, majority of the students $240(80 \%)$ were Yoruba while only 60(20\%) were from outside the Southwest zone of the country. This may not be unconnected with where the schools are domiciled. Majority of the students 245(82\%) were from monogamous family while equal number of students were from each level of the stratum. Nature of the nursing students' family was assessed and the results found that $82 \%$ of the students came from monogamous family and $70 \%$ of the students were Christian .This finding is in consonance with the Charanjeev, Sunita , \& Ravinder (2011) in their study.

Table 2: Correlation Matrix of Variables

\begin{tabular}{|c|c|c|c|c|}
\hline & $\mathrm{A}_{1}$ & $\mathrm{~A}_{2}$ & $\mathrm{~A}_{3}$ & $\mathrm{~A}_{4}$ \\
\hline $\mathrm{A}_{1}$ & 1 & 0.255 & -.078 & .043 \\
\hline $\mathrm{A}_{2}$ & 0.255 & 1 & -.085 & -.122 \\
\hline $\mathrm{A}_{3}$ & -.078 & -.085 & 1 & -.154 \\
\hline $\mathrm{A}_{4}$ & .043 & -.122 & -.154 & 1 \\
\hline
\end{tabular}

$\mathrm{A}_{1}=$ Google, $\mathrm{A}_{2}=$ Wikipedia, $\mathrm{A}_{3}=$ Facebook, $\mathrm{A}_{4}=$ Academic performance

Table 2 presented an inter correlation matrix of Pearson-moment correlation coefficients that showed the correlation among predictor variables in predicting the dependent variable (Students' Academic performance in Nursing). From the correlation matrix of variables, there was glaring proof that the three predictor variables correlated with each other as the correlation all through laid between -1 to +1 that is $-1 \leq \mathrm{r} \leq 1$ (perfect linear negative correlation and perfect linear positive correlation) (Adeyemo, 2005). 
Table 3: ANOVA

\begin{tabular}{|c|c|c|c|c|c|c|}
\hline Model & & Sum of squares & $\mathrm{df}$ & $\begin{array}{c}\text { Mean } \\
\text { Square }\end{array}$ & $\mathrm{F}$ & Sig. \\
\hline \multirow[t]{3}{*}{1} & Regression & 819.125 & 3 & 273.042 & 1.242 & $.300^{\mathrm{b}}$ \\
\hline & Residual & 16709.675 & 276 & 219.864 & & \\
\hline & Total & 17528.800 & 279 & & & \\
\hline \multicolumn{7}{|c|}{ Model Summary } \\
\hline \multicolumn{4}{|c|}{ Model } & 1 & & \\
\hline \multicolumn{4}{|c|}{$\mathrm{R}$} & $.216^{\mathrm{a}}$ & & \\
\hline \multicolumn{4}{|c|}{ R Square } & .047 & & \\
\hline \multicolumn{4}{|c|}{ Adjusted R Square } & .009 & & \\
\hline & & \multicolumn{2}{|c|}{ Std. Error of the Estimate } & 14.82782 & & \\
\hline
\end{tabular}

Predictors: Google, Wikipedia, Facebook

Table 3 illustrates the multiple correlation (R), the multiple correlation squared $\left(\mathrm{R}^{2}\right)$ and adjusted squared multiple correlation $\left(\mathrm{R}_{\mathrm{adj}}\right)$ which reveals how well the set of 3 predictor variables allow reliable prediction of the criterion variable. The model had a positive and high correlation $(\mathrm{R}=.216)$. The $\mathrm{R}^{2}$ which estimated the variance accounted for by independent variables was .047. From the model, we could deduce that about $4.7 \%$ of the total variance in the academic performance of student in Nursing was accounted for by independent variables, leaving the remaining $95.3 \%$ to chance and residual. Table 2 showed that the three predictors (Google, Wikipedia and Facebook) could not predict students performance in Nursing $\left(\mathrm{F}_{(3,76)}=1.242, \mathrm{P}=0.300\right)$. This result is in agreement with the report of Pavlik \& MacIntoch, 2015; Murthy, 2013) but a sharp contrast to Tang, Bin \& Whinston, (2012) in their study on the benefit and contribution of social media among users.

Table 4: Influence of environmental factors

\begin{tabular}{|c|c|c|c|c|c|c|}
\hline Items & SA & A & D & SD & Mean & Std.dev \\
\hline $\begin{array}{c}\text { Students from well } \\
\text { equipped school and } \\
\text { qualified teachers do } \\
\text { not perform } \\
\text { academically better } \\
\text { than others. }\end{array}$ & $\begin{array}{c}66 \\
(21.3 \%)\end{array}$ & $\begin{array}{c}45 \\
(15 \%)\end{array}$ & $\begin{array}{c}120 \\
(40 \%)\end{array}$ & $\begin{array}{c}69 \\
(23.8 \%)\end{array}$ & 2.33 & 1.06 \\
\hline $\begin{array}{c}\text { My zeal for the study } \\
\text { of Nursing has } \\
\text { dropped due to the } \\
\text { teaching method. }\end{array}$ & $\begin{array}{c}19 \\
(6.3 \%)\end{array}$ & $\begin{array}{c}57 \\
(19 \%)\end{array}$ & $\begin{array}{c}117 \\
(39.2 \%)\end{array}$ & $\begin{array}{c}109 \\
(35.4 \%)\end{array}$ & 1.96 & .89 \\
\hline $\begin{array}{c}\text { Inadequate sitting } \\
\text { arrangement had } \\
\text { negative effect on } \\
\text { students' academic } \\
\text { performance. }\end{array}$ & $\begin{array}{c}94 \\
(31.3 \%)\end{array}$ & $\begin{array}{c}120 \\
(40 \%)\end{array}$ & $\begin{array}{c}53 \\
(17.5 \%)\end{array}$ & $\begin{array}{c}33 \\
(11.3 \%)\end{array}$ & 2.91 & .97 \\
\hline $\begin{array}{c}\text { I do not understand } \\
\text { the lesson of my }\end{array}$ & $\begin{array}{c}79 \\
(26.3 \%)\end{array}$ & $\begin{array}{c}94 \\
(31.3 \%)\end{array}$ & $\begin{array}{c}63 \\
(23.8 \%)\end{array}$ & $\begin{array}{c}58 \\
(18.8 \%)\end{array}$ & 2.65 & 1.06 \\
\hline
\end{tabular}




\begin{tabular}{|c|c|c|c|c|c|c|}
\hline $\begin{array}{c}\text { teacher due to } \\
\text { overcrowded } \\
\text { classroom. }\end{array}$ & & & & & \\
\hline $\begin{array}{c}\text { Bad physical } \\
\text { structure of school } \\
\text { building negatively } \\
\text { affects academic } \\
\text { performance of } \\
\text { students. }\end{array}$ & $\begin{array}{c}131 \\
(43.8 \%)\end{array}$ & $\begin{array}{c}124 \\
(41.3 \%)\end{array}$ & $\begin{array}{c}15 \\
(5 \%)\end{array}$ & $\begin{array}{c}30 \\
(10 \%)\end{array}$ & 3.18 & .92 \\
\hline
\end{tabular}

Key: Mean responses ranges from 0-1.0=Strongly disagreed, 1.5-2.0= Disagree, 2.5-

3.0=Agree, 3.5-4.0= Strongly agree

Table 4 shows the influence of school environment on the academic performance of student nurses in South west Nigeria. The result revealed that 'Bad physical structure of school building negatively affect academic performance of students' with a mean of 3.18. This was followed by 'Inadequate seating arrangement' with a mean of 2.91 and overcrowded classroom with 2.65 and 'zeal for the study of Nursing had the least mean of 1.96. This result showed that most students (255 or $85.1 \%$ ) agreed that bad physical structure of the school building had negative influence on academic performance of students. This was followed by Inadequate sitting arrangement (214 or $71.3 \%$ ). About half of the respondents agreed that overcrowded classroom (173 or 57.6\%) had negative influence on the academic performance of students. Whereas, majority (189 or 63.8\%) disagree that students from well equipped school and qualified teachers do not perform academically better than others. Invariably, students from schools with well equipped teachers will perform better than those without. This result supports the assertion of Odeh et al. (2015) who concluded that environmental factors can contribute to students learning outcome.

Table 5: ANOVA

\begin{tabular}{|c|c|c|c|c|c|c|}
\hline Model & & Sum of squares & $\mathrm{df}$ & $\begin{array}{c}\text { Mean } \\
\text { Square }\end{array}$ & $\mathrm{F}$ & Sig. \\
\hline \multirow{2}{*}{1} & Regression & 535.873 & 2 & 267.937 & 1.214 & $.303^{\mathrm{b}}$ \\
\cline { 2 - 7 } & Residual & 16992.927 & 297 & 220.687 & & \\
\cline { 2 - 6 } & Total & 17528.800 & 279 & & & \\
\hline \multicolumn{6}{|c|}{ Model Summary } \\
Model & 1 & \\
R & $.175^{\mathrm{a}}$ & \\
R Square & .031 & \\
Adjusted R Square & .005 & \\
Std. Error of the Estimate & 14.85555 & \\
\end{tabular}

Table 5 illustrates the multiple correlation (R), the multiple correlation squared $\left(\mathrm{R}^{2}\right)$ and adjusted squared multiple correlation $\left(\mathrm{R}_{\mathrm{adj}}\right)$ which reveals how well the set of 2 predictor variables allow reliable prediction of the criterion variable. The model had a positive high 
correlation $(\mathrm{R}=.175)$. The $\mathrm{R}^{2}$ (as $\mathrm{N}>30$ ) which estimated the variance accounted for by independent variables was .031. From the model we could deduce that about $3.1 \%$ of the total variance in student nurses academic performance (contributed by all the independent variables on the dependent variable) was accounted for by independent variables, leaving the remaining $96.9 \%$ to chance and residual. Table 4 equally showed that the two predictors (social media and environmental factors) could not predict students academic performance in Nursing $\left(\mathrm{F}_{(2,77)}=1.214, \mathrm{P}=0.303\right)$. This result corroborates the conclusion of Junco, Heiberger \& Loken (2011) who noted that internet addiction is significantly and negatively related to students' academic performance, as well as emotional attributes. Skog (2005) corroborates Jeong's in Asemah \& Edegoh (2012) assertion, when he opined that the negative influence of internet is only on excessive users and not on all users.

In conclusion, Social media are computer-mediated tools that allow people or companies to create, share, or exchange information, career interests, ideas, and pictures/videos in virtual communities and networks (Buettner, 2016). It is important to state that social media as a subset of technology is of significant importance to the academic achievement of students. The study revealed that social media sites like Google enabled student Nurses to regularly source for educational information on Google, that Wikipedia positively influence acquisition of materials for online academic performance in Nursing, while owning and operating a Facebook account assist students' source for academic information/materials. Similarly, the study was instructive as it revealed that bad physical structure of school building, inadequate sitting arrangement and overcrowded classroom were some of the ways environmental factors ultimately influenced the academic performance. It is therefore recommended that students should be encouraged to use social media to acquire necessary information while government provide conducive learning environment such as e-library for academic excellence.

\section{References:}

1. Adeyemo, P. A (2005). Principles and practice of education. Ile-Ife: University of Ife Press.

2. Ajewole, G.A. \& Okebukola, F.O. (2009). Improving sociocultural aspect of classroom learning environment in enhancing students performance in biology. In Annual Conference Proceeding of Science Teachers Association of Nigeria, (pp127-130). Jos: HEBN Publishers Plc.

3. Akem, J. A. (2008). Continuous assessment: A practical handbook for schools. Makurdi: Selfers academic presslimited. 
4. Arul Laurence, A.S. (2012). School Environment \& Academic Performance of Standard Six Students, Journal of Educational and Industrial Studies in the World, vol. 2, issue 3 article 22.

5. Asemah, E. S.; Okpanachi, R. A. \& Edegoh, L. O. N. (2013).Influence of Social Media on the Academic Performance of the Undergraduate Students of Kogi State University, Anyigba, Nigeria.Research on Humanities and Social Sciences, 3(12), 90-96.

6. Byoung-suk, K. (2012). Landscape Performance Research; School Environment \& Students' Performance, Paper from Landscape Architecture Foundation.

7. Charanjeev, S., Sunita S., Ravinder K.S, (2011) Level of stress and coping strategies used by nursing interns. Nursing and Midwifery Research Journal, Vol-7, No.4.

8. Council for the Advancement of Standards in Higher Education (CAS). (2009). Academic advising programs: CAS standards and guidelines. Retrieved from http:/www.cas.edu/getpdf.cfm?PDF=E864D2C4-D655-8F742E647CDECD29B7D0 on 20 March 2016.

9. Farombi, J. G. (2007). Resource concentration, utilization and management as correlates of students' learning outcomes: a study in School Quality in Oyo State. Unpublished Ph.D. Thesis, University of Ibadan.

10. Grant, N. (2008). On the Usage of Social Networking Software Technologies in Distance Learning Education. In K. McFerrin et al. (Eds.), Proceedings of Society for Information Technology and Teacher EducationInternational Conference 2008. Chesapeake, VA: AACE. 3755-3759

11. Junco, R.; Heiberger, G. \& Loken, E. (2011). The effect of social media on college student engagement and grades. Journal of Computer Assisted Learning, 27(2), 119-132.

12. Madge, C.; Meek, J.; Wellens, J. \& Hooley, T. (2009). Facebook, social integration and informallearning at university: 'It is more for socializing and talking to friends about work than for actually doing work'. Learning, Media, and Technology, 34(2), 141-155.

13. Murthy, D. (2013). Twitter: Social Communication in the Twitter Age. Cambridge: Polity. pp. 7-8.

14. Nauert, R. (2013). Social media, facebook and twitter use may harm grades of college freshman.http://psychcentral.com/news/2013/04/12/social-media-usemay-harm-grades-of-collegefreshman/53711.html. Retrieved 18 March 2016 
15. Nwangwu, N.A. (2009). Universal primary education: Issues, problems and prospects. Benin City: EthiopPublishers.

16. Odeh. R. C.; Oguche, O. A. \& Ivagher, E. D. (2015).Influence of school environment on academic achievement of students in secondary schools in Zone“A" Senatorial District of Benue State, Nigeria. International Journal of Recent Scientific Research, 6(7), 4914-4922

17. Ogbemudia, M. I. and Aiasa, M. V. (2013). Influence of home environment on the academic performance of primary five pupils' in English Language in Orhionmwon Local Government Area of Edo State. Merit Res. J. of Ed. and Rev., 1 (5), 120 - 125

18. Okeke, B. S. (2007). Teaching in Nigeria. The bureaucracy of professionalism 2nd Edition. Port Harcourt: Mercury International Publishing Nigeria.

19. Orlu, C. (2013). Environmental Influence on Academic Performance of Secondary School Students in Port Harcourt Local Government Area of Rivers State.Journal of Economicsand Sustainable Development, 4(12), 34-38.

20. Pavlik, J. \& MacIntoch, S. (2015). Converging Media 4th Edition. New York, NY: Oxford University Press. p. 189.

21. Schroeder, A., Minocha, S., \& Schneider, C. (2010). Social Software in Higher Education: The Diversity of Applications and Their Contributions to Students' Learning Experiences. Communications of the Association forInformation Systems, 26, Article 25(1), 547-564. Skog, D. (2005). Social interaction in virtual communities: The significance of technology. International Journal of Web Based Communities, 1(4), 464-474. Tang, Q.; Bin, G. \& Whinston, A. B. (2012). Content Contribution for Revenue Sharing and Reputation in Social Media: A Dynamic Structural Model". Journal of Management Information Systems 29: 41-75. 